\begin{tabular}{|l|l|l||}
\hline \multicolumn{2}{|c|}{ PublisherInfo } \\
\hline \hline PublisherName & $:$ & BioMed Central \\
\hline \hline PublisherLocation & $:$ & London \\
\hline \hline PublisherImprintName & $:$ & BioMed Central \\
\hline \hline
\end{tabular}

\title{
Shadows provide illumination
}

\begin{tabular}{|l|l|l||}
\hline \multicolumn{2}{|c|}{ ArticleInfo } \\
\hline \hline ArticleID & $:$ & 4712 \\
\hline \hline ArticleDOI & $:$ & $10.1186 /$ gb-spotlight-20030304-01 \\
\hline \hline ArticleCitationID & $:$ & spotlight-20030304-01 \\
\hline \hline ArticleSequenceNumber & $:$ & 64 \\
\hline \hline ArticleCategory & $:$ & Research news \\
\hline ArticleFirstPage & $:$ & 1 \\
\hline \hline ArticleLastPage & $:$ & 2 \\
\hline \hline & & RegistrationDate : 2003-3-4 \\
\hline ArticleHistory & $:$ & OnlineDate \\
\hline \hline ArticleCopyright & $:$ & BioMed Central Ltd2003-4 \\
\hline \hline ArticleGrants & $:$ & \\
\hline \hline ArticleContext & $:$ & 130594411 \\
\hline \hline
\end{tabular}




\section{Richard Robinson}

Email: rrobinson@nasw.org

Comparison of human and mouse DNA sequences has led to the discovery of numerous genes, but is limited by large-scale differences in genomic structure between the organisms. In contrast direct comparisons between humans and primates have been hindered by the very large amount of sequence identity, which can obscure the boundaries of functional regions. In the 28 February Science, Edward Rubin and colleagues at the Lawrence Berkeley National Laboratory, Berkeley, California, US, compared multiple primate genomes to identify exons, regulatory elements, and other features of human genes (Science 229:1391-1394, February 27, 2003).

Rubin et al. compared sequences from more than a dozen primate species, using a technique they call phylogenetic shadowing. While individual species differ little from one another, the additive collective difference of higher primates as a group is comparable to that of humans and mice. In their analysis of differences, they factored in relatedness and compared fast versus slow mutation rates to determine the relative importance of the sequence changes they observed.

Exons displayed the least amount of cross-species variation, and exon-intron boundaries could be accurately and precisely predicted from the degree of collective differences found in their samples. Promoters and enhancers stood out from other noncoding regions due to their relatively conserved sequences. The existence and location of predicted novel control regions were confirmed through transcription factor-binding assays. Deletion of one highly conserved region led to a $55 \%$ decrease in gene expression, versus only $4 \%$ from deletion of a nonconserved region nearby.

The authors conclude such multiple intra-primate comparisons have the potential to identify new genes and new controlling elements, and that further genomic sequencing of primates may allow detailed annotation of the human genome not possible through human-mouse comparisons.

\section{References}

1. An apolipoprotein influencing triglycerides in humans and mice revealed by comparative sequencing.

2. Science, [http://www.sciencemag.org]

3. Lawrence Berkeley Laboratory, [http://www.lbl.gov]

This PDF file was created after publication. 